\title{
МЕТОДОЛОГІЯ ДОСЛІДЖЕННЯ СУДОВОГО ШТРАФУ У СУЧАСНІЙ ПРАВОВІЙ ДОКТРИНІ
}

\author{
КОМАРНИЦЬКИЙ Олег Леонідович - здобувач кафедри загальноправових \\ дисциплін Донецького юридичного інституту МВС України \\ ORCID: https://orcid.org/0000-0003-4038-9906 \\ УДК: 343.271 \\ DOI 10.32782/NP.2020.4.4:
}

У статті проаналізовано можливості за-
стосування найбільш прийнятних методів
наукового дослідження судового штрабу як за
ходу юридичноївідповідальності. Дослідницьку
увагу зосереджено на таких методах наукового
дослідження судового штрабу, як діалектич-
ний, аксіологічний, системний, структурно-
функиіональний метод, методи формальной
логіки, історичний, компаративістський ме-
тоди, психологічні та сочіологічні методи.

Обгрунтовується, що дослідження судового штрафу як заходу юридичної відповідальності має диферениійовано вирішити низку важливих завдань: пізнати природу $і$ сутність судового штрафбу як заходу юридичної відповідальності; визначити ијілі, завдання та призначення застосування судового штрафу як заходу юридичної відповідальності, використовуючи наукові положення сочіології, психологї̈ тощо; сбормулювати основні гіпотези про сутність і особливості впливу судового итрабу як заходу юридичної відповідальності на юридично значущу поведінку осіб, звільнених від юридичної відповідальності за допомогою його застосування.

Робиться висновок про те, що вивчення судового штрафу має враховувати спеиифбіку різних сочіальних, політичних $і$ правових процеесів $i$ явиш. Зазначається, що вирішувати завдання судового штрабу оптимальним шляхом можливо тільки за умови дотримання методологічних принципів, засобів $i$ норм дослідження. Тільки в такому випадку проведене дослідження буде мати теоретичне значення й одночасно дасть змогу наблизитися до ви- рішення практичних завдань судового штрафбу як заходу юридичної відповідальності.

Ключові слова: методологія, метод, юридична відповідальність, захід, судовий штраф, предмет.

Розвиток основ правової демократичної держави, формування національної системи права зумовлюють необхідність поглибленого вивчення теоретичних основ проведення досліджень у правовій сфері.

На шляху пізнання методологійних основ дослідження судового штрафу як іншого заходу кримінально-правового характеру знаходяться певні перепони. Зараз у правовій науці в цілому спостерігається використання вже давно напрацьованого матеріалу, фактично відсутне накопичення нового наукового знання.

Тривалий час підходи, принципи і методи дослідження правових явищ не були об'єднані на певні рівні, форми і види. 3 розвитком наукового знання методологія поступово виділилася в специфічний предмет пізнання й утвердилася як багаторівнева система соціально апробованих принципів, правил і засобів теоретичної і праксеологічної діяльності. Тому в сучасній науці найбільш поширеною є концепція про багаторівневий характер методології наукового пізнання. Щодо змісту цього багаторівневого характеру методології в науці існують різні погляди.

Безсумнівним є твердження про те, що чим складніше предмет пізнання, чим багатогранніші форми його прояву в суспільному 


\section{Теорія, історія держави і права, конституційне право}

житті, тим більшу кількість методів варто застосовувати під час його дослідження. Виникає питання: яке коло і яку рівневу структуру методів вибрати в процесі дослідження судового штрафу? Набір методів і особливо система їх інтерпретації в межах кожного рівня методології матиме свої особливості, свою специфіку, яка залежить від граней, спрямованості та специфіки предмета дослідження. Методику дослідження необхідно вибудовувати залежно від предмета пізнання.

Методологія пізнання судового штрафу повинна бути розподілена на такі рівні: філософсько-світоглядний, загальнотеоретичний, спеціально-теоретичний, конкретнонауковий.

Крім зазначених рівнів, важливе значення для наукового дослідження має також використання загальних принципів методології наукового пізнання. Серед них: принцип єдності теорії і практики; принцип об'єктивності; принцип всебічності дослідження; принцип єдності історичного i логічного; принцип системності; принцип детермінізму; принцип діалектичного розвитку; принцип достовірності [1, с. 97].

На філософсько-світоглядному рівні методології формується певне синтетичне знання про судовий штраф, його місце в соціальному бутті і правовій реальності, що 6 синтезом досягнень філософії і теорії держави і права. На цьому рівні методологія виступає як керівна ідея, система світоглядних принципів.

Специфіка філософсько-світоглядного рівня методології пізнання судового штрафу полягає в тому, що тут використовуються не конкретні методи (у класичному їх розумінні), а цілісні методологійні підходи, що дають змогу дізнатися про різні аспекти судового штрафу в різнопланових його взаємозв'язках 3 елементами суспільного життя і визначають основний шлях, стратегію вирішення поставленого завдання [2, с. $40]$.

Методологійною основою загальнотеоретичного рівня пізнання судового штрафу є загальні теоретичні принципи наукового пізнання, дослідницькі підходи, система методів, способів. Загальнонаукова методологія визначає загальні методи і засоби піз- нання, їх можливості і межі застосування. Серед загальнонаукових методів пізнання можна назвати: аналітико-синтетичний метод, методи абстрагування і конкретизації; методи індукції та дедукції; метод моделювання; спостереження; експеримент тощо. Відповідно, вони поділяються на теоретичні та емпіричні.

Загальнонаукова методологія встановлює відповідні норми, критерії та форми пізнання, покликані виключити упередженість, суб'єктивність і логічну непослідовність самого процесу пізнання і його результатів.

Спеціально-теоретичний рівень методології пізнання судового штрафу охоплює методологію пізнання юридичної відповідальності. Ця методологія не зобов'язує дослідника до використання чітко визначеного переліку методів, оскільки наукове пізнання - це процес творчий. Тому в процесі дослідження певної проблеми юридичної відповідальності дослідник використовує конкретно-наукові методи.

Конкретно-наукова методологія - це комплекс методів, що застосовується в конкретній галузі знань для пізнання властивого тільки їй об’єкта дослідження. Для теорії юридичної відповідальності базовими, головними об'єктами конкретно-наукового дослідження є правопорушення, особа правопорушника та заходи юридичної відповідальності.

Методологічні основи дослідження судового штрафу визначено специфікою останнього як складного правового явища. У цьому контексті необхідним $є$ розуміння значущості змістовної інтерпретації предмета. Адже у теорії права існують різні концептуальні підходи до розуміння поняття судового штрафу, його галузевої приналежності тощо. Тому від змістовної інтерпретації предмета дослідження залежить обрання відповідних методів.

Дослідження судового штрафу як заходу юридичної відповідальності має диференційовано вирішити низку важливих завдань: пізнати природу і сутність судового штрафу як заходу юридичної відповідальності; визначити цілі, завдання та призначення застосування судового штрафу як заходу юридичної відповідальності, використовую- 
чи наукові положення соціології, психології тощо; сформулювати основні гіпотези про сутність і особливості впливу судового штрафу як заходу юридичної відповідальності на юридично значущу поведінку осіб, звільнених від юридичної відповідальності за допомогою його застосування.

Певні методологічні проблеми безпосередньо пов'язані з особливостями самого об'єкта дослідження.

Перша проблема, яка утруднює дослідження, - це проблема емпіричних даних. Офіційні показники стану застосування судового штрафу не відображають дійсної картини і, відповідно, не дають повного уявлення про обсяги і характер його впливу. До сих пір немає розробок про методики дослідження судового штрафу як заходу юридичної відповідальності.

Друга проблема наукового дослідження судового штрафу як заходу юридичної відповідальності - це інтеграція емпіричних даних для виявлення певних тенденцій, побудови гіпотез і самостійної теорії. Теоретичні висновки за результатами дослідження судового штрафу не можуть такою мірою, як в емпіричних або експериментальних дослідженнях, відповідати загальним критеріям науковості з погляду методології науки. Судження про судовий штраф не мають дедуктивного характеру i, отже, не можуть бути підтверджені повністю емпіричними, а також експериментальними дослідженнями. Тобто теоретичні положення не можна послідовно вивести одне з одного, як у природничих науках. За таких умов особливо важлива роль у дослідженні судового штрафу належить гіпотезі. Третя проблема, яка також виникає 3 вимог методології науки, - обов'язковість можливості перевірки гіпотез і, відповідно, підтвердження істинності (науковості) самої теорії й побудова на цій основі обгрунтованих прогнозів. Перевірка гіпотез, природно, $\epsilon$ необхідним складником наукового дослідження. Без неї дослідження певною мірою втрачає право претендувати на істинність.

Тому наукові судження про судовий штраф як захід юридичної відповідальності в тій частині, у якій неможлива верифікація гіпотез, вимагає визначення відповідних критеріїв істинності (науковості). До того ж, необхідно пам'ятати, що більшість теоретичних узагальнень і гіпотез мають лише ймовірнісний характер. У цьому випадку дедуктивного правила перевірки гіпотези не існує, і тому можна відзначити лише часткове підтвердження або верифікацію гіпотези [2, с. 261].

Засобом реалізації всіх цих вимог $\epsilon$ створення програми дослідження судового штрафу. За наявності тих методологійних труднощів, про які вже було сказано, у дослідженні важливо чітко визначити завдання, які потребують вирішення, сформулювати коло проблемних питань, уточнити використовувані поняття, а також системно визначити всі використовувані методи. Це буде сприяти «методологійній озброєності» дослідження.

Розглянемо найбільш значущі для нашого дослідження методи.

У юридичній науці діалектичний метод визначає загальні напрямки й підходи до вивчення юридичних явищ, інститутів і норм права. На основі діалектики наука теорії права розробляє свої методи, відповідні iї цілям і завданням, а також особливостям досліджуваних явищ.

С. С. Алексєєв, вивчаючи специфіку законодавчих практик, відзначав, що «... своєрідність юридичної матерії, яка характеризується тим, що притаманна їй повинність виражається в юридичних нормах законних прав, представляє дивовижний сплав «належного» і «можливого», точніше - такого «належного», яке для суб'єктів виявляється як суб'єктивні права, тобто юридичні можливості» [3, с. 391]. Він підкреслив діалектичний взаємозв'язок можливого і реального як одну 3 найважливіших внутрішніх характеристик динамічності права: «Юридичні норми вводяться в дію саме для того, щоб наявні в них положення про належне i можливе ставали, за наявності певних умов, реальністю, фактично втілилися в життя» [3, с. 389]. У системі філософської науки діалектична логіка утворює єдність 3 діалектикою й теорією пізнання.

Використання законів i категорій діалектики в дослідженні судового штрафу дає змогу з'ясувати походження, сутність і соціальну зумовленість цього явища правової 


\section{Теорія, історія держави і права, конституційне право}

дійсності, визначити форми впливу судового штрафу на суспільне життя, закономірності функціонування й розвитку й на цій основі сформулювати рекомендації щодо їх удосконалення, спрогнозувати історичні перспективи останніх.

Аксіологічний підхід до розуміння судового штрафу має значення в контексті ціннісного розуміння права, що виходить 3 розгляду його як частини культури, ціннісно-соціальної реальності. Виходячи 3 цього, цінності - це свого роду сутнісна основа права. Завдяки їм право отримує власний сенс, формуються дозволи, заборони, зобов'язання. Вони знімають момент байдужості в поведінці суб'єкта права, без них існування феномена права стає неможливим. Ціннісний аспект правової реальності досліджує такий розділ філософії права, як правова аксіологія, завданням якої 6 аналіз правових цінностей та ідеалів [4, с. 12].

Аксіологічне дослідження судового штрафу має важливе наукове, практичне й моральне значення, оскільки дає змогу звернути увагу не тільки на соціокультурні основи його застосування, зв’ язок з державою, але й на його духовні аспекти, ідеали, рівень свідомості суспільства. Без ціннісного підходу до розуміння судового штрафу неможливо виявити його призначення в загальнолюдському, соціальному й культурному розвитку, зрозуміти його специфічну природу. До того ж, аксіологічне дослідження судового штрафу дає змогу говорити про дотримання або недотримання загальноприйнятих людських цінностей, ідеалів і стандартів під час його застосування.

Серед загальнонаукових методів пізнання правової реальності одним 3 найбільш ефективних є системний аналіз. У сучасній правовій доктрині існує стійка тенденція до його використання.

Учені завжди приділяли достатньо уваги вивченню проблематики, пов'язаної з системою законодавства і його системністю. Саме системний підхід досить активно використовували при проведенні правових досліджень [5, с. 27]. Для успішного використання системного аналізу необхідно розглянути поняття «система», «системний аналіз», їх гене- зис, можливості застосування в дослідженні судового штрафу.

Першим значним кроком у процесі вирішення будь-якої конкретної проблеми системного дослідження $є$ уявлення досліджуваного як системи. Від цього певною мірою залежить успіх дослідження [6, с. 31]. Це безпосередньо стосується й судового штрафу як заходу юридичної відповідальності.

Незважаючи на певну суперечливість i парадоксальність системного аналізу, застосування цього методу пізнання сприяє адекватній постановці проблем у конкретних науках і виробленню ефективної стратегії їх вивчення. Специфіка системного аналізу визначається тим, що він орієнтує дослідження на розкриття цілісності об'єкта, на виявлення різноманітних типів зв'язків складного об'єкта й зведення їх у єдину теоретичну картину [7, с. 39].

Використовуючи системний метод пізнання, необхідно, насамперед, виходити зі специфіки самого об'єкта дослідження (у контексті нашої статті - судового штрафу як заходу юридичної відповідальності). Необхідно розглядати об'єкт як систему, яка поєднує в собі різні підсистеми й сама перебуває в полі- і макросистемній реальності.

Досліджуваний нами елемент юридичної відповідальності є досить складним і багатоаспектним. Він може проявлятися у вигляді одиничного об'єкта суспільного життя звільнення конкретної особи від юридичної відповідальності 3 призначенням судового штрафу. Більш системно він проявляється на рівні теорії юридичної відповідальності, механізму правового регулювання суспільних відносин. Комплексно сутність інституту судового штрафу виявляється в міждисциплінарних зв'язках з іншими юридичними науками. Усі правові норми, що утворюють інститут судового штрафу, створюють нерозривну системну нормативну єдність.

Метод структурно-функційного аналізу. У сучасній філософській і правовій літературі є різні підходи до трактування цього поняття. Зокрема, у межах позитивізму поняття «структура» визначають через систему зв'язків між елементами. Таке визначення повністю відповідає методологійному принципу детермінізму. Залежно від змісту детер- 
мінувальних зв'язків елементів структури у філософії й правовій науці вказували на різні види детермінації (такі, як причинність, взаємозалежність, кореляційний зв'язок, цільова детермінація тощо). Стверджували, що всі види детермінації так чи інакше пов'язані між собою. А детермінація в правовій сфері значною мірою визначається особливостями соціальної детермінації [8, с. 35].

Необхідність застосування структурнофункціонального методу пізнання судового штрафу як заходу юридичної відповідальності полягає в розробці найбільш адекватної й оптимальної структури правових норм, на основі яких і застосовують судовий штраф.

Досить широко використовуються методи формальної логіки в процесі пізнання судового штрафу як заходу юридичної відповідальності. За допомогою логіко-юридичного методу коментуються положення законодавства. Значення цього методу пояснюється тим, що правові норми є, по суті, системою формалізованих понять, пов'язаних певною логікою, і розкрити їхній зміст неможливо без використання логіко-юридичного аналізу. Широке використання цього методу в праві виробляє особливий стиль мислення, коли будь-яке поняття розкладається на складові частини й кожній дається визначення, оцінка [9, с. 115].

Логіко-юридичний (або догматичний) метод заснований на використанні правил формальної логіки для пізнання права. Його значення в процесі пізнання судового штрафу полягає в з'ясуванні змісту правових норм, що регламентують застосування вказаного заходу кримінально-правового характеру.

Абстрагування - мисленнєвий відхід від деяких властивостей і зв'язків досліджуваного й виділення властивостей і відносин, які цікавлять дослідника. Зазвичай при абстрагуванні другорядні властивості й зв'язки досліджуваного об'єкта відокремлюються від істотних властивостей і зв'язків. Види абстрагування: ототожнення, тобто виділення загальних властивостей і зв'язків предметів, що вивчаються, встановлення тотожного в них, абстрагування від відмінностей між ними, об'єднання предметів в особливу групу; ізолювання, тобто виділення деяких властивостей і зв'язків, що розглядаються як самостійні предмети дослідження.

Прикладом абстрагування може слугувати процес утворення юридичних понять. Ці поняття є змістовними науковими абстракціями [10, с. 44]. Наприклад, юридичне визначення судового штрафу не відображає всіх його властивостей, а містить найбільш суттеві з них.

Історичний метод пізнання судового штрафу. Дослідження історії зародження, розвитку й еволюції правових явищ є традиційним предметом дослідження юридичної науки. Зміст історичного методу полягає в з'ясуванні сутності досліджуваного об'єкта за допомогою аналізу його історії (розвитку) 3 урахуванням всієї їі багатогранності. Цей метод використовується для ретроспективного вивчення проблем права, закономірностей і тенденцій розвитку вітчизняного законодавства, чинників, що впливають на його розвиток, виявлення впливу зарубіжного законодавства на розвиток вітчизняного.

Для обрання раціональних напрямків подальшого розвитку вітчизняного права особливого значення набувають порівняльні наукові дослідження. I це пов’язано з тим, що юридична наука в жодному разі не повинна обмежувати себе рамками однієї держави. До якої $б$ сфери практичної діяльності ми не звернулися, скрізь очевидна важливість знання зарубіжного права.

У контексті пізнання судового штрафу слід зазначити, що вітчизняне право як наука розвивається, не тільки накопичуючи нові знання про свій предмет, а й формулюючи нові напрямки наукових досліджень, серед яких в останні десятиліття виділяється правова компаративістика. Розвиток методологічної бази вітчизняних правових досліджень сприяє становленню філософії права, формуванню нових наукових підходів, постановці проблем концептуального характеру його актуалізації для сучасної вітчизняної правової науки.

Ідея використання порівняльного методу в дослідженні судового штрафу базується на тому, що праву іманентні часові та просторові відносно стійкі відмінності. Саме тривалість у часі й повторюваність певних правових явищ 3 можливою їх трансформацією спонукає вчених до пошуку й розробки 


\section{Теорія, історія держави і права, конституційне право}

найбільш оптимальних моделей правових норм тощо.

Дослідження досвіду інших країн у правовій регламентації судового штрафу є одним із напрямів пошуку оптимальних правових конструкцій, використання яких дасть змогу уникнути певних помилок і скористатися кращим зарубіжним досвідом.

Психологічні та соціологічні методи пізнання судового штрафу. Необхідно розуміти, що, з одного боку, у процесі пізнання судового штрафу, психологічні та соціологічні методи набувають специфічних рис, зумовлені особливостями об'єкта пізнання. 3 іншого - особливості використання в правових дослідженнях методів психологічної та соціологічної науки зумовлені специфікою предметів зазначених наук.

3 огляду на все зазначене, доцільним видається зробити висновок про те, що вивчення судового штрафу має враховувати специфіку різних соціальних, політичних i правових процесів і явищ.

Вирішувати завдання судового штрафу оптимальним шляхом можливо тільки за умови дотримання методологійних принципів, засобів і норм дослідження. Тільки в такому випадку проведене дослідження буде мати теоретичне значення й одночасно дасть змогу наблизитися до вирішення практичних завдань судового штрафу як заходу юридичної відповідальності.

\section{Аітература}

1. Бермус А.Г. Введение в гуманитарную методологию: монография. М.: «Канон+» РООИ «Реабилитация», 2007. 336 с.

2. Рузавин Г.И. Методология научного познания: Учебное пособие для вузов. М.: ЮНИТИ-ДАНА, 2012. 287 с.

3. Алексеев С.С. Право. Азбука. Теория. Философия: Опыт комплексного использования. М.: Статут, 1999. 712 с.

4. Алексеева Т.А. Справедливость. Морально-политическая философия Джона Роулса. М.: Наука, 1992. 112 с.

5. Коробова А.П. О понятии и природе правовой политики. Правовая политика $и$ правовая жизнь. 2003. № 3. С. 24-32.

6. Гребеньков Г.В. Очерки по философии права: Монография; Донецкий юридиче-

\section{SUMMARY}

The article analyzes the possibilities of using the most acceptable methods of scientific research of a court fine as a measure of legal responsibility. Research attention is focused on such methods of scientific research of a judicial fine as dialectical, axiological, systemic, structural-functional method, methods of formal logic, historical, comparative methods, psychological and sociological methods.

It is substantiated that the study of a court fine as a measure of legal responsibility has a differentiated solution to a number of important tasks: to understand the nature and essence of a court fine as a measure of legal responsibility; to determine the goals, objectives and purpose of applying a judicial fine as a measure of legal responsibility, using the scientific provisions of sociology, psychology, etc. to formulate the main hypotheses about the nature and characteristics of the impact of a court fine as a measure of legal responsibility on the legally significant behavior of persons released from legal responsibility through its application.

It is concluded that the study of a court fine should take into account the specifics of various social, political and legal processes and phenomena. It is noted that it is possible to solve the problems of a court fine in an optimal way only if the methodological principles, means and norms of research are observed. Only in this case, the conducted research will be of theoretical significance and at the same time will allow one to approach the solution of the practical problems of a court fine as a measure of legal responsibility.

Key words: methodology, method, legal responsibility, event, court fine, subject.

ский институт Ауганского государственного университета им. Э.А. Дидоренко, 2009. $216 \mathrm{c}$.

7. Ковалев М. И., Воронин Ю. А. Криминология и уголовная политика. Свердловск: Изд-во УрГу, 1980. 58 с.

8. Овчинников С. И. Принцип детерминизма в методологии правоведения. Правоведение. 1984. № 2. С. 35-39.

9. Криминология. Под общ. ред. А.И. Долговой. М.: Узд. Группа Норма-Инфра-М, 2001. 784 с.

10. Сабитов Р. А. Основы научных исследований: Учеб. Пособие. Челяб. гос. ун-т. Челябинск, 2002. 138 с. 